\title{
LAW REVIEW OF ELECTRONIC LIABILITY REGISTRATION AS A FULFILLMENT OF PUBLICITEIT BASIS IN INDONESIA
}

\author{
https://doi.org/10.47743/jopafl-2021-22-28
}

\author{
Putri Ayi WINARSASI \\ Faculty of law, Universitas Antakusuma, \\ Indonesia \\ putriwinarsasii@gmail.com
}

\begin{abstract}
Guarantee agreements for immovable objects such as land/buildings, the provisions of Law Number 4 of 1996 concerning Mortgage on Land and objects. To improve mortgage services meet the principles of openness, timeliness, speed, convenience and affordability, it is necessary to utilize information technology, mortgage service procedures can be integrated electronically become more effective and efficient. Spatial Planning of the Head of the National Land Agency Number 9 of 2019 concerning Electronic Integrated Mortgage Services which has been effective since its promulgation. The Ministerial Regulation Number 3 of 2019 concerning the use of electronic systems and 7 of 2019 is concerning changes in the form of certificates. The various ministerial regulations is a step forward and expected to make it easier for the public to get services, especially Electronic HT registration by utilizing technological developments, considered suitable with the current situation of the Indonesian state which are facing the COVID-19 outbreak.
\end{abstract}

Keywords: Legal Review; Registration; Mortgage; Publiciteit Principle; Legal Guarantee

\section{Introduction}

According to J. Satrio stated that Legal Guarantee is legal regulations which arranged about collateral for a creditor on the debtor, then law guarantee is law arranged about the guarantee someone's debt (Satrio, 2002). Besides that, Salim H.S also gives formulation of law guarantee which is a whole rule of law which arranged relationship between guarantee of giver and receiver in the relationship with guarantee charge to get the credit facility (Salim, 2007). From the two opinions above, on the formulation of the definition of guarantee law which can be concluded that the core of law guarantee is legal provisions governing the legal relationship between the guarantor or debtor and recipient of the guarantee or creditor as imposition of a certain debt or credit with a guarantee (certain object or person). The Material rights that used as a debt repayment (security rights) are collateral rights which attached to creditors who give the authority to execute objects that are used as collateral if debtor defaults on achievement. If there are a creditors who wants a higher position, more than fellow concurrent creditors, then creditor can agree on the collateral rights, both individual guarantee rights, such as debtors and a borgs that gives him a better position, because there are more than a person who can be billed, as well as an agreement on the right of material security that gives him the right to take precedence in taking payment of the proceeds from selling of certain objects or group of certain objects belonging to debtor, guarantor, and sometimes it is also facilitated in exercising his rights (Widodo et al., 2019). Every activity of banks and credit distributions is needed a juridical provision which become the basic of law. This as a consequence from principals that 
Indonesia is a country of law, where law and regulation occupies very important order as a source of law. Likewise for a legal act of granting credit, of course it also requires a strong legal basis. The legal basis for granting credit includes:

Article Number 1338 paragraph (1) Civil Law state that "All agreements made legally apply as law to those who make them". Therefore, with the provisions in Article 1338 paragraph (1), it applies that every agreement made legally, even its strength is similar as the power of law. In Indonesia, the law that specifically regulates Banking is Law Number 10 of 1998 which regulates Amendment to Law Number 7 of 1992 concerning Banking. The definition of banking is strictly regulated, based on Article 1 paragraph (1) of the Law of the Republic of Indonesia Number 10 of 1998 concerning Amendments to Law Number 7 of 1992. Which states that: "Banking is everything related to banks, including institutions, business activities, as well as the methods and processes in carrying out its business activities. Marhainis Abdul Hay which stated that: "Credit Agreements are identical to borrowing agreements and are governed by the provisions of Chapter XIII of Book III of the Civil Code” (Hay, 1975). The same thing was also stated by Mariam Darus BadruIzaman: "From the formulation contained in the Banking Law regarding Credit Agreements, it can be concluded that the basis of credit agreement is a loan agreement" in the Civil Code Article 1754. This loan agreement also contains broad meaning, namely the object is an object that runs out if verbruiklening includes money. Based on this loan agreement, the loan recipient becomes the owner of loan and must then returns same type to the lender. Therefore, this credit agreement is a real agreement, namely that the occurrence of a credit agreement is determined by "delivery" of money by bank to the customer (Badrulzaman, 1994).

The conditions for the validity of an agreement are generally regulated in the Article 1320 of Civil Code. There are 4 (four) conditions that must be met for the validity of the agreement. The conditions such as:

1. Their deal that reminded him;

2. The ability to make an agreement;

3. A certain thing;

4. A lawful cause.

Credit agreements needed special attention, either by banks as creditors or debtors, because the credit agreement is the basis of contractual relationship between the parties. From the credit agreement, various things can be traced regarding the granting, management, or administration of the credit itself. According to Gatot Wardoyo, credit agreements have several functions:

a. The credit agreement functions as a principal agreement, meaning that credit agreement is something that determines whether or not other agreements that follow it are canceled, such as a guarantee binding agreement.

b. The credit agreement serves as evidence regarding the boundaries of rights and obligations between creditors and debtors.

c. The credit agreement serves as a tool for monitoring credit (Ibrahim, 2004).

The Civil Code (KUH Perdata) is formulated in Articles 1131 and 1132 of the Civil Code. In Article 1131 of the Civil Code it is stated that: "All objects of the debtor, both movable and immovable, both existing and new will exist in the future, become dependents for all individual engagements". The specific provisions concerning banking legislation which is do not explain the position of creditors. The provisions governing credit 
guarantees are contained in Law Number 7 of 1992 concerning Banking, Article 8 which states that: "In providing credit, Commercial Banks must have confidence in the ability of debtor to pay off his debts in accordance with the agreement".

The Act of the Republic of Indonesia Number 7 Of 1992 Concerning Banking as Amended by Act Number 10 of 1998 stated that: Paragraph (1): "In extending Credits or Financing based on Sharia Principles, a Commercial Bank shall have confidence based on thorough analysis on the intention, capability and ability of a Debtor Customer to repay its debt or the financing according to the agreed terms. Paragraph (2): A Commercial Bank shall formulate and implement guidance on Credit and Financing is based on Sharia Principles, according to regulations stipulated by Bank Indonesia”.

In implementing the credit agreement, it can be made with deed both the private deed and an authentic deed in accordance with applied the law and regulation. The credit agreement which is followed by a guarantee agreement for material in the form of immovable goods such as land or buildings is called a Mortgage Rights (HT), and then it must be followed by the registration of Mortgage Rights to fulfill the principle of publicity (publiciteit).

\section{Theoretical Framework}

\section{Definition of Mortgage Rights}

According to the online large Indonesian dictionary, the definition of mortgage is goods that are used as collateral (he borrows money from the bank with a plot of land) while the notions of Mortgage is the guarantee given by borrower to lender in any form in accordance with the agreement https://kbbi.kemdikbud.go.id. Furthermore, according to the provisions of Article 1 paragraph 1 of Law Number 4 of 1996 the definition of mortgage is: "Mortgage rights on land and objects related to land, hereinafter referred to as Mortgage Rights, security rights imposed on land rights as referred to in paragraph (1). In the Law Number 5 of 1960 concerning Basic Regulations on Agrarian Principles, including or not including other objects which are an integral part of the land, for the settlement of certain debts, which give priority to certain creditors over other creditors”.

\section{The principle of Mortgage Rights}

In the law of guarantees there are 5 principles, namely as follows:

1. The principle of publicity is namely the principle that all rights, both mortgage rights, fiduciary rights, and mortgages must be registered. This registration is intended so that third parties can know that the collateral is being charged. Registration of mortgage rights at the Land Agency Office, Regency/City National, fiduciary registration is carried out at the Fiduciary Registration Office at the Office of the Ministry of Justice and Human Rights, while the registration of ship mortgages is carried out in front of the registrar and, the registrar of names, namely the harbormaster;

2. The principle of speciality, namely that mortgage rights, fiduciary rights, and mortgages can only be charged on a small amount or on goods that have been registered in the name of a certain person;

3. The principle of indivisibility, namely the principle that debt can be divided cannot result in the distribution of mortgages, fiduciary rights, mortgages, and liens even though partial payments have been made. 
4. The principle of inbezittstelling, namely the collateral (pawn) must be with the recipient of the pledge;

5. The horizontal principle, namely the building and land are not a single unit. This can be seen in the use of rights of use, both state land and property rights. The building belongs to the person concerned or the mortgagee, but the land belongs to someone else, based on the rights of use (Salim, 2007).

below:

While, principle of mortgage right according to Purwahid Patrik, explained as

\section{Principle of publiciteit}

Principle of publiciteit can be known from the article number 13 paragraph 1 law of mortgage right which stated that the granting of mortgage rights must be registered at the Land Office of the point, therefore by registering the mortgage right is the absolute condition to create a mortgage right and bonding a mortgage right on the third party.

Principle of Specialiteit

Principle of specialiteit can be known from the explanation in the article number 11 paragraph 1 law of mortgage right which stated that the provision is determined the content which is mandatory for the validity of the APHT mortgage granting deed, Indeed it is not stated in full that the things mentioned in the APHT result in the deed in question being null and void.

\section{Principle of indivisibility}

Principle of indivisibility pointed out that in the article 2 paragraph 1 Mortgage law stated that the definition of indivisible nature of mortgage is a Mortgage encumbrance in its entirety the object of Mortgage and every part thereof. The payment of part of the guaranteed debt does not mean the release of part of the mortgage object from the burden of the mortgage, but the mortgage still burdens the entire mortgage object for the remaining debt that has not been paid off. Whereas, the exception from principle of indivisibility is found in the constitutions of article 2 paragraph 2 which stated that if the mortgage right charged to some rights that can be promised in the relevant APHT. That the guarantee debt repayment which can be implemented with the installment payment as much as the value of each land right which is part of the object of the mortgage that will be released from the mortgage right, then the mortgage only burdens the student the object of the mortgage to guarantee the remaining debt that has not been paid off (Patrik and Kashadi, 2009).

\section{Subject Of Mortgage Right}

The subject of the mortgage right arranged in the article 8 and 9 constitutions number 4 of 1996 concerning about the mortgage right in both article is determined which become Legal subjects in the assignment of mortgage rights are mortgage providers and mortgage holders at the point of mortgage granting can be individuals or legal entities that have the authority to take legal actions against of the mortgage right object. The holder of mortgage right is consisting of individual or law institutions which domiciled as a debtor. It is commonly in the practice of granting mortgage which called with debtor, which is people borrow money from banking institutions while mortgage rights are called creditors, namely people or legal entities that are domiciled as parties to the debt (Salim, 2007). 


\section{Object of Mortgage Right}

Basically not every land right can be debt guarantee but land right which can be the guarantee must be fulfilled the condition as follows: It can be assess with money because the debt that is guaranteed in the form of money is included in the rights listed in the general register, because it must meet the publicity requirements, it is transferable because if the debtor is breach the contract, the object used as collateral for the debt will be sold in public and require appointment by law. In civil code and the regulation concerning credit verband and staatsblad 1908-504 as it has changed with Staatsbald 1937-190 has been arranged concerning mortgage object and including: 1. Ownership right; 2. Building right; 3. Cultivation right. While, in the article number 4 and 7 from 1996 constitutions number 4 has been expressly appointed land rights that can be used as collateral for debts, there are 5 kind of land right which can be guaranteed with the mortgage rights namely: 1 . Ownership right; 2. Cultivation right; 3. Building right; 4. right of use, both ownership rights and land rights, state rights; 5 . land rights including existing or future plant buildings and works are an integral part of the land, which are the property rights of the land rights holder, the burden of which is expressly and stated in the deed of granting rights to the land concerned (Salim, 2007).

\section{Registration of Mortgage Right}

It stated among other in point 7, the general explanation above Mortgage Right Laws on the stage of granting mortgage rights by the mortgagee to the creditor, the concerned of mortgage right is not created. The mortgage is created when it is recorded in the land book at the Land Office. It is known that the granting of mortgage rights as outlined in the APHT must be followed by registration obligations by way of being recorded in the land book at the Land Office which at the same time determines the birth of the mortgage right. The obligation to register mortgage rights is further emphasized in Article 13 paragraph 1 of the UHT which states that the granting of mortgage rights must be registered at the Land Office. There are some explanation in the article 13 paragraph 1 means stated a principle of mortgage right is publiciteit principle therefore the registration of mortgage granting is the absolute condition to creating the mortgage right and bond the mortgage right on the third party. Therefore, the registration of mortgage right in the land book at the Land Office who implemented in order ti fulfilling the publiciteit principle because during At the time of the signing of the Mortgage Agreement, a new one was born, namely the promise to provide a new Mortgage Right when the HP was registered in the Land Book at the Land Office. For this reason, the granting of Mortgage Rights must or must be followed by registration in the Land Book at the land office is an absolute prerequisite for the birth of mortgage rights and although bond the mortgage right on third party. Therefore the certainty related mortgage right registration is important for creditor and not only determining the main position on the other creditorexcept also determine its rating in relation to other creditors who are also holders of mortgage rights with the same land as collateral. Rachmadi Usman, SH, (2009) means the registration of mortgage right is important to implemented related with the appearance of preferred claim rights from creditors which determine the creditor's position rating against fellow preferred creditors and determine the creditor's position in the event that there is a confiscation of collateral on the collateral parcel (Satrio, 2002). 


\section{The Characteristic Of Mortgage Right}

The Mortgage rights as the only institution for guaranteeing land rights for the settlement of certain debts has fourth kinds of characteristic as follows (Adrian Sutedi, 2010):

Gives the priority position to creditor. This means that the creditor holds mortgage right has the right to take precedence in paying off their debts rather than the other creditors above the result of proceeds from the sale of the object for which the mortgage is encumbered.

Always follow the object in the hands of whoever the object is. It means that the objects that are used as the object of the Mortgage are still burdened by the Mortgage even though in the hands of whomever the object is. Although, the land right which become the Mortgage Right object has been transferred or moves to the other people but the mortgage right which still on the object and still has the power to bond it.

Fulfilling the specialiteit and publiciteit, specialiteit principle means the good that granting the mortgage right it must be stated explicitly and clearly regarding what the object being burdened is in the form of, where it is located, how wide it is, what the boundaries are, the funds on the proof of the owner. There are the publiciteit principle means that the mortgage right granting must be known by public, therefore, the Deed of Granting Mortgage must be registered.

Easy and sure the execution of the execution, means can be execute such as judge decision which a judge's decision that has permanent and definite legal force.

\section{Methodology}

This research used normative law method which commonly called as doctrine law or library research. It called the doctrine law research because the research is only referred to the written law so this research is closely related to the library because it will needed the data which in the secondary data in the library. In this research, the normative law that written is studied from various aspect such as theory, philosophy, comparison, structure/composition, consistency, the general explanation and explanation of every article, formality and power to bond a constitutions and language that used is legal language.

The approach method that the author uses is normative juridical. According to Soerjono Soekanto, the normative juridical approach is the legal research which implemented with the how to research library materials or secondary data as the basic law to analyze with how to conduct a search of regulations and literature which related with the analyzes problem (Soekanto and Mamudji, 2001). Researcher discuss and analyzing related the law of Mortgage right registration electronically (HT-el) as the fulfillment the publiciteit principle in law guarantee, based on the regulation of applied law and regulations.

\section{Result and Discussion}

The registration of Mortgage Right electronically

The function of juridical guarantee, that guarantee is something has a value included in the transaction in order to guarantee the debt. Without including guarantee so 
it only happens when a contract for debt or receivable and it is an obliged to pay. According to Prof. Dr. R. Subekti, S.H. stated that the ideal credit guarantee is:

1. Which can easily assist in obtaining the credit by the party in needs;

2. Which does not weaken the potential (strength) of the credit seeker to carry out (continue) his business;

3. Which provides certainty to the creditor, in the sense that the collateral is available for execution at any time, i.e. if necessary, it can be easily cashed to pay off the debt of the credit recipient (taker).

Guarantee is the protection facility for the creditor security which is certainty above repayment of debtor's debt or implementation of an achievement by debtor or by guarantor. The existence of a guarantee is a requirement to minimize the risk of banks in lending (Widodo, Pranjoto and Efendi, 2018). However, in guarantee principle is not the main requirement. The Bank prioritizes and the feasibility of the business it finances as the main guarantee for credit repayment according to a mutually agreed schedule. As the anticipation's step to attract in withdrawing funds that have been distributed by creditors to debtors, two factors should be considered, namely:

\section{Secured}

It means credit guarantee can be legally binding in accordance with the regulation of law and regulation. If, in the next day happens wanprestasi from debtor, therefore bank has the juridical power of implementing the executions.

\section{Marketable}

This means if the guarantee is about to be executed, it can be immediately sold or cashed to pay off all debtor's obligations. By considering the two factors above, the guarantee received by the bank can minimize the risk in lending in accordance with the prudential banking principle. Normatively, the meaning of protection for creditors is listed in various statutory provisions. Law Number 4 of 1996 concerning Mortgage on land and objects related to land, or it is known as the Mortgage Law (HT), which regulates guarantees where the objects are in the form of land, buildings, land and buildings. Prior to the enactment of HT (mortgage) Law, and in accordance with the provisions of Article 51 of the Basic Agrarian Law (UUPA) mortgages on land apply, as regulated in the Indonesian Civil Code and Credietverband as regulated in Koninklijk Besluit in Staatsbald. 1908 No. 452 as amended by Staatsbald 1937 No. 190 (Supramono, 2009).

According to the regulation in the Article 51 UUPA known that mortgage object in the form of land is stipulated in the provisions of article 25 (right of ownership), article 33 (right of use), and article 39 (right of building). The three land rights are objects of mortgage rights according to the law because:

a. The right according to the applicable provisions must be registered in the general register at the land office. This element relates to the preferred position given to creditors holding mortgage rights over other creditors. With registration, the registration of mortgage rights in the land book and certificates of land rights that are encumbered with these rights, other people can find out.

b. These rights, by their nature, must be transferable so that if necessary, they can be realized immediately to pay off debts whose settlement is guaranteed (Supramono, 2009). 
The Provisions regarding electronic HT (Mortgage Right) registration according to the Regulation of Minister of Agrarian Affairs and Spatial Planning of Head of the National Land Agency Number 9 of 2019 concerning Electronically Integrated Mortgage Services regulates, among others, the following:

The definitions of Mortgage up to the Land Office can be seen in the provisions of Article 1 number 1 to number 15. Article 1 number 1 , Mortgage on land and objects related to land, hereinafter as referred to Mortgage, is a guarantee right imposed on land rights as referred to in Law Number 5 Year 1960 concerning Basic Regulations on Agrarian Principles, including or not of the other objects which are an integral part of the land, for the settlement of certain debts, which give priority to certain creditors over other creditors. Article 1 point 4, Land Deed Official, hereinafter abbreviated as (Land Deed Officer) PPAT is a public officials who is authorized to make a deed of land rights transfer, deed of encumbrance of land rights, and deed of granting power to impose Mortgage Rights according to the provisions of legislation. Article 1 point 5, Deed of Granting Mortgage, hereinafter abbreviated as APHT, is a deed of PPAT which contains the granting of Mortgage to certain creditors as collateral for guarantee for repayment of debts. Article 1 point 6, Electronically Integrated Mortgage Service, hereinafter referred to as the HT-el System, is a series of mortgage service processes in the context of maintaining land registration data which is carried out through an integrated electronic system. Article 1 number 7, Electronic System is a series of electronic devices and procedures that function to prepare, collect, process, analyze, store, display, announce, transmit, and/or disseminate electronic information. Article 1 point 8, Electronic Document is an electronic information which created, forwarded, sent, received, or stored in analog, digital, electromagnetic, optical, or similar forms, which can be seen, displayed, and/or heard through a Computer or Electronic System. It is including but not limited to writing, sounds, pictures, maps, designs, photographs or the like, letters, signs, numbers, access codes, symbols or perforations that have meaning or can be understood by people who are able to understand them. Article 1 number 9, Electronic Domicile is domicile of the parties in the form of verified electronic mail addresses and/or cellular phone numbers. Article 1 number 10, Registered Users are service users who meet the requirements as users of HT-el System with the rights and obligations regulated by the Ministry. Article 1 number 11, Electronic Signature is a signature consisting of Electronic Information attached, associated or related to other Electronic Information used as verification and authentication as referred to in the Electronic Information and Transaction Law.

In the Article 3 paragraph (1) Mortgage services are carried out in accordance with the provisions of the laws and regulations governing service standards and land regulations within the Ministry. In the article 3 paragraph (2) Mortgage services as referred to in the paragraph (1) can be carried out electronically through the HT-el System. In the Article 4 paragraph (1) HT-el system is administered by the Land Office. In the article 4 paragraph (2) HT-el system as referred to in the paragraph (1) is implemented in stages according to the readiness of supporting data. In the article 4 paragraph (3) Determination of the Land Office that operates HT-el System is carried out by Minister in accordance with the readiness of supporting data as referred to in paragraph (2). In the article 5 paragraph (1) HT-el system is operated reliably and safely and responsible for the operation of the electronic system. In the Article 5 paragraphs (2) HT-el system as referred to in paragraph (1) a certified system from the authorized agency. Regarding the type of service, it is 
contained in the provisions of Article 6, Types of Mortgage services can be submitted through HT-el System, includes:

a. Mortgage Registration;

b. Transfer of Mortgage Rights;

c. Change of creditor name; and

d. Elimination of Mortgage.

Arrangements regarding Service Users can be seen in the provisions of Article 7 paragraph (1) Users of the HT-el System service, including:

a. Individuals/legal entities as creditors as regulated in the laws and regulations governing Mortgage Rights; and

b. Ministry of State Civil Apparatus in charge of serving Mortgage Rights.

Paragraph (2) the individual/legal entity as referred to in paragraph (1) point a must be a Registered User on HT-el System.

Paragraph (3) becomes a Registered User as referred to in paragraph (2), an individual/legal entity registers on the HT-el System with the following conditions:

a. Have an electronic domicile;

b. Certificate of Registration with the Financial Services Authority;

c. Statement of fulfillment of the requirements and criteria as well as approval of the provisions as a Registered User; and

d. Other conditions determined by the Ministry.

Paragraph (4) The Ministry shall verify the registration as referred to in paragraph (3) and has the right to refuse the registration.

Regarding the provisions for registered users, it can be seen in the provisions of Article 9 Paragraph (1) Registered Users apply for Mortgage services electronically through the HT-el System provided by the Ministry. Paragraph (2) the requirements for the application for Mortgage services as referred to in paragraph (1) are in accordance with the provisions of the legislation. The application for Mortgage registration can be seen in the provisions of Article 10 Paragraph (1) In the event that the application for services is in the form of Mortgage registration. The requirements for the application in the form of APHT are submitted by PPAT in the form of Electronic Documents. In the Paragraph (2) APHT submission is done through an electronic system that is integrated with the HT-el System. Paragraph (3) The mechanism for submitting APHT as referred to in paragraph (2) is carried out in accordance with the provisions of legislation.

In the article 11 paragraph (1) the service application which has been accepted by HT-el system gives the proof of application registration which published by system. Paragraph (2) the proof of registration application as it means in the paragraph (1) is containing about: a. Application registration file number;

b. Application registration date;

c. Applicant's name; and

d. Service fee payment code

The registration fee for Mortgage is regulated in the provisions of Article 12 Paragraph (1) Mortgage Service which is imposed in accordance with the provisions of the laws and regulations concerning Non-Tax State Revenue at the Ministry. Paragraph (2) After obtaining the proof of registration as referred to in Article 11, the applicant shall make payment through the perception bank no later than 3 (three) days after the date of application registration. 
In the Article 13 Paragraph (1) Certificate Mortgage Service by recording Mortgage in the land book and Land Rights or Property Rights of Flat Units. In the paragraph (2) The registration of Mortgage Rights in the relevant land book is carried out by the Head of Land Office. In the paragraph (3) The registration of Mortgage Rights on Land Rights Certificates or Flat Ownership Units can be implemented by Creditors with records issued by the HT-el System. In the paragraph (4) Creditors attached the printed records as referred to in paragraph (3) on the Certificate of Land Rights or Property Rights of the Flat Units. In the paragraph (5) Notes as referred to in paragraph (3) shall become an integral part of the Mortgage Certificate. In the article 14 paragraph (1) The results of Mortgage services through the HT-el System are in the form of:

Certificate of Mortgage Right; and

Mortgage records on the land book and the Certificate of Land Rights or Ownership of Flat Units. In the article 14 paragraph (2) the result of service as it means on the paragraph (1) in the form of Electronic Document which published by HT-el system. Paragraph (3) keeping to maintain the integrity and authenticity of Electronic Documents, Mortgage Certificates which published by HT-el system. Paragraph (4) the electronic signature is implemented in accordance with the provision of legislation. Paragraph (5) the publication of the service result of mortgage right as referred to in paragraph (1) shall be carried out on the 7th (seventh) day after the submission of a confirmed application.

Paragraph (6) the form of the Mortgage Certificate and notes on the Mortgage encumbrance are made in accordance with the format as it contained in Attachment II which is an integral part of this Ministerial Regulation. Article 15 paragraphs (1) before the results of Mortgage Service are issued, the Head of Land Office or appointed official must examine the concept of the HT-el certificate and documents for completeness of the application.

In the article 15 paragraph (2) The Head of Land Office or the appointed official as referred to in paragraph (1) administratively responsible for the results of the Mortgage Service. In the paragraph (3) In the event that the Head of Land Office or appointed Official does not carry out the inspection as referred to in paragraph (1), the Head of Land Office or appointed Official is deemed to have given approval. Article 16 Paragraph (1), the Mortgage Certificate resulting from the transfer of Mortgage Rights, change of creditor name, or partial abolition of Mortgage Rights, is issued with the same number as previous certificate, which contains data on the latest changes. Paragraph (2) the previous certificate as referred to in paragraph (1) is given a special sign that the certificate is not valid (Winarsasi, 2020). The Mortgage Right registration is obliged to implemented by Creditor after fulfill terms and Conditions apply as fulfilling publiciteit principle when before the Mortgage Right registration is implemented individually, now it can be implemented electronically is in accordance with the provisions of the Regulation of Minister of Agrarian Affairs and Spatial Planning of the Head of National Land Agency Number 9 of 2019 concerning Electronic Integrated Mortgage Services.

\section{Conclusion}

The credit agreement is the primary agreement which commonly followed with accesoir agreement which is the material guarantee agreement in the form of immovable object such as Land/building is known with Mortgage right (HT) and made in the form of authentic deed by Land Deed Making Officials (PPAT), such as SKMHT and APHT, then 
implementing the registration to fulfilling publiciteit principle or publicity, as regulated in the provisions of Law Number 4 of 1996 concerning Mortgage on Land and objects related to Land. With the issuance of Regulation of the Minister of Agrarian and Spatial Planning/Head of the National Defense Agency Number 9 of 2019 concerning Electronically Integrated Mortgage Services, there has been a change in the registration of Mortgage Rights at the Land Office (ATR/BPN), which was originally manually to electronically (online) which is known as the HT-el system, hope that this will make it easier for the public and creditors in registering Mortgage Rights so that they meet the publiciteit principle. The type of Mortgage Right service which can be applied through Htel system is containing:

a. registration of Mortgage Rights;

b. transfer of Mortgage Rights;

c. change of creditor name; and

d. abolition of Mortgage

There are the fees charged in the mortgage registration process electronically (HTel) arranged in the Provisions Article 12 paragraph (1) Mortgage services are subject to a fee, in accordance with provisions of legislation regarding Non-Tax State Revenue (PNBP) applicable to the Ministry of Agrarian Affairs and Spatial Planning/National Defense Agency.

\section{References}

1. Adrian Sutedi (2010) Hukum Hak Tanggungan. Jakarta: Sinar grafika.

2. Hay, M. A. (1975) Hukum Perbankan di Indonesia. Bandung: Pradnya Paramita.

3. Ibrahim, J. (2004) Mengupas Tuntas Kredit Komersial Dan Konsumtif Dalam Perjanjian Kredit Bank (Perspektif Hukum Dan Ekonomi). Bandung: Mandar Maju.

4. Patrik, P. and Kashadi (2009) Hukum Jaminan. Semarang: Badan Penerbit Universitas Diponegoro.

5. Rachmadi Usman, SH, M. (2009) Hukum Jaminan Keperdataan Cetakan kedua. Jakarta: Sinar Grafika.

6. Salim, H. S. (2007) Perkembangan Hukum Jaminan di Indonesia. Jakarta: PT. Raja Grafindo Persada.

7. Satrio, S. H. (2002) Hukum Jaminan, Hak Jaminan Kebendaan, Hak Tanggungan Buku I. Bandung: PT.Citra Aditya Bakti.

8. Soekanto, S. and Mamudji, S. (2001) Penelitian hukum normatif: Suatu tinjauan singkat. RajaGrafindo Persada.

9. Supramono, G. (2009) Perbankan dan Masalah Kredit (Suatu Tinjauan Dibidang Yuridis). Jakarta: PT. Rineka Cipta.

10. Widodo, I. G. et al. (2019) 'Constraints on Enforcement of Environmental Law Against Corporate Defendants’, Environmental Policy and Law. doi: 10.3233/EPL-190129.

11. Widodo, I. gunadi, Pranjoto, E. W. and Efendi, J. (2018) 'Law Liability of Construction Failure in Indonesia’, International Journal of Civil Engineering and Technology, 9(11), pp. 2363-2371.

12. Winarsasi, P. A. (2020) Hukum Jaminan di Indonesia, Perkembangan Pendaftaran Jaminan secara Elektronik. Surabaya: Jakad Publishing.

This article is an open access article distributed under the terms and conditions of the (1) (9) Creative Commons Attribution - Non Commercial - No Derivatives 4.0 International License. 